\title{
Hypolipidemic Effect of Eggplant Peels (Solanum melongena, L) Powder on Obese Rats
}

\author{
Amal N. Zaki \\ Nutrition and Food Science \\ Department, Faculty of Home Economics, \\ Menoufia University, Egypt
}

\begin{abstract}
Eggplant, (Solanum melongena, L.) is one of the vegetables ranked highest in total antioxidant capacity, it is contains high concentrations of phytochemicals such as phenolic acids and flavonoid compounds that have high antioxidant activity, In this paper, the effect of Eggplant Peels Powder (EPP) on reduce cholesterol and lipid profile in obese rats and improve their health were investigation. Twenty five male albino rats weighting $140 \pm 10 \mathrm{~g}$ were used in this study and divided into 5 groups, each group contain 5 rats. Rats were treated by high fat diet $(30 \%$ animal fat) to induce obese and to raise cholesterol level and lipid profile in blood. First (control group), second, third and fourth group received basal diet $+0,1,2$ and $4 \%$ of dried eggplant peels powder (EPP), respectively for 4 weeks. Animals were sacrificed, blood samples were collected. Serum was then removed by centrifuging for analysis. Chemical composition and phenolic compounds in eggplant peels were determined. Total cholesterol (TC), triglycerides (TG), lipoprotein fraction (HDL-c, LDL-c, VLDL-c), atherogenic indices (AIP, CRR, CRI,AF and AC), and serum liver functions (ALT, AST, and ALP) were also determined. Data from obese rats revealed that the eggplant peel showed significant changes in the tested biochemical parameters. As conclusion, obese rats treated with 4\% eggplant peel powders had improved lipid profile levels and showed markedlly significantly decreased of hyperlipidemic effect compared with other concentrations.
\end{abstract}

Keywords: Rats, eggplant peel, hyperlipidemic effect, lipid profile and Pytochemicals. 


\section{INTRODUCTION}

Hyperlipidemia is abnormally elevated levels of any or all lipids or liporoteins in the blood (Fung et al., 2011). Hyperlipidemia refers to increased levels of lipids (fats) in the blood, including cholesterol and triglycerides. Although hyperlipidemia does not cause symptoms, it can significantly increase your risk of developing cardiovascular disease, including disease of blood vessels supplying the heart (coronary artery disease), brain (cerebrovascular disease), and limbs (peripheral vascular disease). These conditions can in turn lead to chest pain, heart attacks, strokes, and other problems. (Sameer et al., 2011). Hyperlipidemias are divided into primary and secondary subtypes. Primary hyperlipidemia is usually due to genetic causes (such as a mutation in a receptor protein), while secondary hyperlipidemia arises due to other underlying causes such as diabetes (Helmja et al., 2007). Lipid and lipoprotein abnormalities are common in the general population and are regarded as modifiable risk factors for cardiovascular diseasedue to their influence on atherosclerosis. In addition, some forms may predispose to acute pancreatitis.. Since cholesterol is insoluble in water, it is transported in the blood plasma within protein particles (lipoproteins), Lipoproteins are classified by their density: Very low density lipoprotein (VLDL), intermediate density lipoprotein (IDL), low density lipoprotein (LDL) and high density lipoprotein (HDL) (Biggerstaff and Wooten, 2004). All the lipoproteins carry cholesterol, but elevated levels of the lipoproteins other than HDL (termed non-HDL cholesterol), particularly LDLcholesterol are associated with an increased risk of atherosclerosis and coronary heart disease (Carmena et al., 2004). In contrast, higher levels of HDL cholesterol are protective (Kontush and Chapman, 2006). Elevated levels of non-HDL cholesterol and LDL in the blood may be a consequence of diet, obesity, inherited (genetic) diseases (such as LDL receptor mutations in familial hypercholesterolemia), or the presence of other diseases such as diabetes and an underactive thyroid (Varghese, 2014).

Reducing dietary fat is recommended to lower total blood cholesterol and LDL in adults (Hooper et al., 2012). In people with very high cholesterol (e.g. familial hypercholesterolemia) diet is often insufficient to achieve the desired lowering of LDL, and lipid lowering medications which reduce cholesterol production or absorption are usually required. If necessary other treatments, including LDL special treatment or even surgery (for particularly severe subtypes of familial hypercholesterolemia) are performed (Ito et al., 2011).

Eggplant (Solanum melongena, L.) also is an important crop of subtropical and tropical regions. This fruit presents low caloric value and is a good source of minerals, vitamins and anthocyanins. Eggplant has also received great attention due to its high antioxidant activity and medicinal properties, and its consumption is recommended for diabetic patients (Zaro et al., 2015). Eggplant contains many bioactive 
constituents capable of producing a range of health effects; in which it contains polyphenols, flavonoids, minerals, vitamins, etc which are reported to possess numeral medicinal properties as revealed by (Nisha et al., 2009). It has also high fiber, low fat and hence low energy content (Zevnik, 2009). Furthermore, eggplant fruit contain ascorbic acid and phenolics, both of which are powerful antioxidants Oxidative stress can cause oxidative damage to large biomolecules such as proteins, DNA, and lipids, resulting in an increased risk for cancer and CVD. To prevent or slow down the oxidative stress, sufficient amounts of antioxidants need to be consumed (Temple et al., 2006). Meanwhile, eggplant ranked among top ten vegetables for free radical scavenging activity (Nisha et al., 2009). Eggplant is a good source of phenolics and anthocyanins-linked antioxidant activity by free radical scavenging or metal ion chelating that reduce risk of chronic disease as showed by several researches as (Nisha et al., 2009). This in addition to induce phenolsulfotransferases (PSTs) activities, which are known as phase II detoxifying enzymes with cancer prevention potential by eggplant extract at $100 \mu \mathrm{g} / \mathrm{ml}$; this correlated to phenolic content and antioxidant activity as found by Yeh and Yen (2005). Hanson et al., (2006) pointed to the need to evaluate skin and pulp samples separately of eggplant due to specific types of phenols which differ between skin and pulp of eggplant and that revealed by Huang et al., (2004) they reported that total phenolics content of eggplant skin is about two times greater than its pulp.

Eggplant has been known to be useful in many regions and folk medicine (Oboh et al., 2005); and the use of eggplant have been suggested to treat different diseases (Capriles et al., 2002). Although no controlled studies but eggplant can have a good effects related to diabetes and hypertension based on that showed by Kwon et al., (2001) that phenolic-enriched extracts of eggplants had $\alpha$-glucosidase and angiotensin converting enzyme (ACE) inhibitory activities which provide a strong biochemical basis for management of type 2 diabetes by controlling glucose absorption and reducing associated hypertension, and that indicated by some authors of high fiber and low soluble carbohydrate content, as well as antioxidant activity of eggplant. This in addition to previously mentioned of a considerable $\mathrm{K}$ content of eggplant as found by chemical analysis of some researches as Ejoh $\boldsymbol{e t}$ al., (1996). Furthermore, eggplant has been used as hypocholesterolemic agent in many countries; however few controlled studies were addressed to this subject and atherogenesis Botelho et al., (2004). Eggplant extract as a hypocholesterolemic agents has some support but needs more study (Lans, 2006). The results of eggplant or its components extract in lipid metabolism is controversial between studies showed beneficial effects, reducing the hypercholesterolemia in animals or showed antioxidant activity such as for example Kahlon. et al., 2007, and on the other hand some studied found no significant effects as(Silva et al., 2004). Moreover, eggplant was found to have anticarcinogenic and antimutagenic activity as found by some researches as Azevedo et al., (2007). Also, Duke et al., (2002), pointed 
to previous and many other eggplant indications such as obesity, anaphylaxis, bleeding, hepatosis, dysuria, infection,.. and others, which all need further studies. Therefore, the objective of this study is to evaluate some potential therapeutic effects of eggplant.

This work was conducted to study the effect of Eggplant Peels Powder (EPP) on reduce cholesterol and lipid profile in obese rats and improve their health.

\section{Material and Methods}

\section{Materials}

The plant used in this study was eggplant peels (Solanum melongena, L.) which were obtained from the local market of Shebin El-Kom City, Menoufia Governorate, Egypt in 2017, while, Casein, cellulose, choline chloride powder and DL- methionine powder were obtained from Morgan Co. Cairo, Egypt.

\section{The chemical kits}

Chemical kits used for determination the (TC, TG, HDL-c, ALT, AST, ALP) were obtained from Al-Gomhoria Company for Chemical, Medical and Instruments, Cairo, Egypt.

\section{Experimental animals}

A total of 25 adult normal male albino rats Sprague Dawley strain weighing $140 \pm 10 \mathrm{~g}$ were obtained from Vaccine and Immunity Organization, Ministry of Health, Helwan Farm, Cairo, Egypt.

\section{Methods}

\section{Preparations of eggplant peels}

Eggplant was obtained from local market. Plant was cleaning, washing, peeling and dehydrating at room temp $\left(40^{\circ} \mathrm{C}\right)$ for 24 hours, the dried peels were ground in mixer and grinded for a soft powder without impurities.

To prepare the dried eggplant peels powder, peels were washed thoroughly under running tap water, shade dried, and ground to a fine powder using an air mill, high speed mixture (Molunix, Al-Araby, company, Egypt, and then serving as powder size.

\section{Chemical analysis of eggplant peels}

Samples were subjected to chemical analysis in order to determine: moisture, protein, fat, fiber, ash and some minerals (sodium, potassium and iron) according to AOAC method (2000). Total phenols content also were determined by the folinciocalteu method Meda et al., (2005). In addition to the identification of phenolic compounds by HPLC according to the method outlined by Ben-Hammouda et al., (1995).

\section{Induction of experimental obesity and hyperlipidemia}

Obesity was induces in normal healthy male albino rats by fed on high fat diet (30\% animal lipid) supplemented in the basal diet and used as a positive control group.

\section{Experimental design}

Twenty five adult male white albino rats, Sprague Dawley Strain, 10 weeks age, weighing $(140 \pm 10 \mathrm{~g})$ were used in this experiment. All rats were fed on basal diet (casein diet) prepared according to AIN, (1993) for 7 consecutive days. After this adaptation period, rats are 
divided into 5 groups, each group which consists of five rats as follows: Group (I): Rats fed on basal diet and used as negative control. Group (2): Obese rats induced by fed on high fat diet (30\% animal lipid) supplemented in the basal diet ( $0 \%)$ EPP and used as a positive control group. Group (3): Group infected obesity with rats was fed EPP by $1 \%$ of the weight of diet. Group (4): Group infected obesity with rats was EPP by $2 \%$ of the weight of diet. Group (5): Group infected obesity with rats was fed EPP by $4 \%$ of the weight of diet. During the experimental period, the body weight and feed intake were estimated weekly and the general behavior of rats was observed. The experiment period was take 28 days, at the end of the experimental period each rat weight separately then, rats are slaughtered and collect blood samples. Blood samples were centrifuged at $4000 \mathrm{rpm}$ for ten minute to separate blood serum, and then kept in deep freezer till using.

\section{Blood sampling}

After fasting for 12 hours, blood samples in initial times were obtained from retro orbital vein, while it obtained from hepatic portal vein at the end of each experiment. Blood samples were collected into a dry clean centrifuge glass tubes and left to clot in water bath $\left(37^{\circ} \mathrm{C}\right)$ for 30 minutes, then centrifuged for 10 minutes at $4000 \mathrm{rpm}$ to separate the serum, which were carefully aspirated and transferred into clean cuvette tube and stored frozen in deep freezer till analysis according to method described by Schermer, (1967).

Biochemical analysis

Lipids profile

\section{Determination of total cholesterol}

Serum total cholesterol was determined according to the colorimetric method described by Thomas (1992).

Determination of serum triglycerides

Serum triglyceride was determined by enzymatic method using kits according to the Young, (1975) and Fossati, (1982).

Determination of high density lipoprotein (HDL-c)

HDL-c was determined according to the method described by Friedwaid (1972) and Grodon \& Amer (1977).

Calculation of very low density lipoprotein cholesterol (VLDL-c)

VLDL-c was calculated in mg/dl according to Lee and Nieman (1996) using the following equation:

VLDL-c $(\mathrm{mg} / \mathrm{dl})=$ Triglycerides $/ 5$

Calculation of low density lipoprotein cholesterol (LDL-c)

LDL-c was calculated in $\mathrm{mg} / \mathrm{dl}$ according to Lee and Nieman (1996) as follows: LDL-c $(\mathbf{m g} / \mathbf{d l})=$ Total cholesterol - HDL-c VLDL-c

The atherogenic ratios were calculated as follows:

Atherogenic Index of Plasma (AIP) $=\log$ TG/HDLc, Cardiac risk ratio $(\mathrm{CRR})=$ TC/HDLc Castelli's Risk Index $(\mathrm{CRI})=$ LDLc/HDLc Atherogenic Coefficient $(\mathrm{AC})=(\mathrm{TC}-\mathrm{HDLc}) / \mathrm{HDLc}$ according to Bhardwaj et al., (2013) and Atherogenic fraction (AF) was calculated as the difference between TC and HDL-C according to Aguilar et al., (2011). 


\section{Liver functions}

Determination of serum alanine amino transferase (ALT), serum aspartate amino transferase (AST), serum alkaline phosphatase (ALP) were carried out according to the method of Hafkenscheid (1979); Clinica Chimica Acta (1980), and Moss (1982), respectively.

\section{Statistical analysis}

The data were analyzed using a completely randomized factorial design (SAS, 1988) when a significant main effect was detected; the means were separated with the Student-Newman-Keuls Test. Differences between treatments of $(\mathrm{P} \leq 0.05)$ were considered significant using Costat Program. Biological results were analyzed by One Way ANOVA.

\section{RESULTS AND DISCUSSION}

Data presented in Table (1) show the percent of chemical composition content of eggplant peel which it was riches in water, fiber and protein, respectively on wet weight. The values were $90.3 \%, 30.3 \%$ and $8.1 \%$, respectively and that is good for lipid profile parameter where were they reducing their level of blood. Also, according to Huang et al., (2004) established high moisture content for eggplant meat and skin as $93.12 \%$ and $92.31 \%$, respectively. Moreover, Kala and Prakash (2006) defined the chemical composition of brinjal (eggplant) per $100 \mathrm{~g}$ dry weight basis as $92.7 \mathrm{~g}$ moisture, $12.69 \mathrm{~g}$ protein, $6.46 \mathrm{~g}$ ash, $1.95 \%$ ether extract (crude fat), $37.2 \mathrm{~g}$ fiber, $242 \mathrm{mg} \mathrm{Ca}, 338$ $\mathrm{mg}$ P, $6.12 \mathrm{mg} \mathrm{Fe}$, and $21.73 \mathrm{mg}$ vitamin C. Also, Kahlon et al., (2007) reported that $36.9 \mathrm{~g}$ fiber, $15.5 \mathrm{~g}$ protein, $0.9 \mathrm{~g}$ fat, $7.9 \mathrm{ash}$, and $75.7 \mathrm{~g}$ carbohydrate for $100 \mathrm{~g}$ eggplant on dry weight basis.

Data in Table (2) elucidated the results as fresh weight basis indicated similar trends and showed great lower levels than that as dry weight basis indicating that drying process lead to concentrate the nutrients and phenol content by deleting moisture. These results are in agreement with Huang et al., (2007), they illustrated that total phenolics content of eggplant skin is about two times greater than eggplant pulp (267 and 118.1 g of gallic acid equivalents / $100 \mathrm{~g}$ fresh weight respectively). Moreover, Helmja et al., (2007) they indicated that skin extract of eggplant have the highest total phenolic and flavonoid contents being $1.5 \mathrm{~g} / \mathrm{l}(900 \mathrm{mg} / 100 \mathrm{~g})$ and $1.1 \mathrm{~g} / \mathrm{l}(660 \mathrm{mg} / 100 \mathrm{~g})$ respectively compared to vegetables of the solanaceae family (tomato, chilli pepper, and potato). Also, Raigon et al., (2008) reported that phenolics content of eggplant as $48.26 \mathrm{mg} / 100 \mathrm{~g}$ fresh weight. Furthermore, Nisha et al., (2009) examined the total phenolic content of four different varieties of eggplant and the mean value was 71.78 $\mathrm{mg} / 100 \mathrm{~g}$.

Data given in Table (3) evident that a total number of 12 different phenolic compounds were estimated in eggplant peels, being 3 phenolic compound were (pyrogallic acid, protocatechuic acid and orthocoumaric acid). The major phenolic compound for peels were 
orthocoumaric acid then pyrogallic acid finally protocatechuic acid (16.74258, 7.22519 and $2.06367 \mathrm{mg} / 100 \mathrm{~g}$., respectively)

Helmja et al., (2007) explained that eggplant skin extract have the highest total phenolic and flavoniod contents $1.5 \mathrm{~g} / \mathrm{L}(900 \mathrm{mg} / 100 \mathrm{~g})$ and $1.1 \mathrm{~g} / \mathrm{L}(600 \mathrm{mg} / 100 \mathrm{~g})$ respectively compared to vegetables of Solanoceae family (tomato, chilli pepper, and potato); and the polyphenols found in skin extract of eggplant are phenolic acids (chlorogenic acid, cinnamic acid, caffeic acid, and ferulic acid). Furthermore, the skin extract of $S$. melongena mainly phenolic compounds were determined using capillary zone electrophoresis (CZE) and liquid chromatography - diode array detection-tandem mass spectrometry (HPLC-MS/MS) by Helmja et al., (2009) who identified the following substances: (1) Cinnamic, caffeic, quinic and p-coumaric acids, (2) isomers of chlorogenic acid, (3) caffeicacid conjugate, (4) cinnamic acid derivative, (5) isomers of dihydroxycinnamoyl aminde, (6) N,N- dicaffeoyl spermidine. The traces of quercetin rutinoside and various kaempferol glycosides were identified as well. Nasunin was determined by MS/MS only as a minor component of the extract. In this respect, it is worthy mention that Nasunin, a major anthocyanins in eggplant peel that responsible for its color, comprises two isomers, cis and trans isomers of the delphinidin 3-[ 4- (p- coumaroyal) - L rhamnosyl (1-6) glucopyranoside ] -5- glucopyranoside.

Table (4) data of this table showed the effect of EPP on liver enzymes ALT /AST and ALP and found that the significant increase in group which feed rats on basal diet only $(0 \%)$ EPP. The values were $192.30 \pm 0.20,57.62 \pm 1.14$ and $22.80 \pm 0.10 \mathrm{U} / \mathrm{L}$., respectively. However, when adding the EPP for diet with varity level 1,2 and $4 \%$ found that the significant decrease and the most effective group was feed rats on (4\%) EPP. The values were $(118.6 \pm .10,24.90 \pm 1.13$ and $11.55 \pm .30$ U/L., respectively. Duke et al., (2002) pointed to indications of eggplant which involved hepatosis. Also, Guimaraes et al., (2000) indicated that eggplant infusion $2 \%$ were apparently harmless as suggested by normal levels of alkaline phosphatase and gammaglutamyl trans peptidase in individuals, in which some vegetables may cause hepatic injuries when administered in large amounts to rats and humans, probably due to antinutritional factors such as tannin or alkaloids. But, the finding by Friedman et al., (1996) showed that feeding of potato, tomato, and eggplant alkaloids affects liver weight in mice, since eggplant alkaloids increased relative liver weight, these finding should serve as guide for removal of the most toxic compounds from plant foods. This finding did not observed in the present groups with feeding on eggplant fruit parts inwhich there were insignificant changes in liver weight.

Table (5) elucidated the effect of EPP on total cholesterol and triglycerides on obese rats and found that rats which feed on basal diet alone $(0 \%)$ EPP were high significantly than all groups in T.C and T.G $(130.00 \pm 1.10$ and $134.25 \pm 1.21 \mathrm{mg} / \mathrm{dl}$., respectively). While feeding rats on basal diet added to it (4\%) EPP were more effective to decrease T.C and T.G which recorded $(110.00 \pm 0.10$ and $62.55 \pm 0.30 \mathrm{mg} / \mathrm{dl}$, respectively). Eggplant flavonoids extract showed significant 
hypolipidemic action in normal and cholesterol fed rats which showed in cholesterol fed rats significant reduction of serum and different organs cholesterol, serum TG level, liver and kidney phospholipids, and serum and liver free fatty acids as noticed by Sudheesh et al., (1997) who also pointed to bile acids binding properties of flavonoids by observation of significant increase in hepatic and fecal bile acids and explain this effect; which come in agree with the results by Kahlon et al., (2007) who pointed to bile acid binding capacity of vegetables as eggplant and explained that binding bile acids and increasing their fecal excretion has been hyposised as a possible mechanism by which dietary fiber lowers cholesterol. Reducing bile acid recirculation lowers cholesterol by reducing fat absorption and use of synthesized cholesterol to synthesize bile acid. So, this property is related to lowering risk of heart disease. When usesed steam cooking for eggplant, a significantly improved in vitro bile acid binding of eggplant than uncooked one.

Table (6) showed the effect of EPP on lipid profile (HDL / LDL and VLDL) on obese rats, it is clear that the significantly increased for LDL and VLDL in groups which feed rats on basal diet without any addition $(0 \%)$ which were $(78.05 \pm 1.20$ and $26.85 \pm 1.13 \mathrm{mg} / \mathrm{dl}$., respectively). per contra the level of HDL the significant decreased which was $(29.35 \pm 1.41 \mathrm{mg} / \mathrm{dl})$. Maximum improvement of HDL /LDL and VLDL recorded for $(4 \%)$ EPP groups which were $(37.80 \pm 1.13$, $59.69 \pm 0.20$ and $12.51 \pm 0.20 \mathrm{mg} / \mathrm{dl}$., respectively).

Table (7) this table summarizes the effect of EPP on atherogenic indices (AI:Atherogenic Index in Plasms, CRR: Cardiac Risk Ratio, AF: Atherogenic Fraction, AC: Atherogenic Coefficient, and CRI : Castellis Risk Index). It is showed the groups which were administrated EPP were significantly decrease in AIP, CRR, CRI, AF and AC than the groups which feed on basal diet alone $(0 \%)$ group.More effective reduction in AIP, CRR, CRI, AF and AC were observed in rats feed on basal diet and 4\% EPP which were $(2.40 \pm 0.20,2.91 \pm 0.10,1.58 \pm 0.12$, $72.20 \pm 0.35$ and $1.91 \pm 0.12 \mathrm{mg} / \mathrm{dl}$., respectively). Atherogenic indices are powerful indicators of the risk of heart disease the higher the value, the higher the risk of developing Cardiovascular Disease (CVD) and vice versa (Usoro et al., 2006). Also, Eggplant had activities of antioxidant, hypocholesterolemic, antiatherosclerotic and LDL peroxidation inhibition by at least $90 \%$ by its skin as observed by Huang et al., (2004) which come in parallel to that suggested by

Table 1: The Chemical Composition of Eggplant Peel(EP) (g/100g)

\begin{tabular}{|c|c|}
\hline Quantity & Compounds \\
\hline Moisture & $90.3 \mathrm{~g} / 100 \mathrm{~g}$ \\
\hline Ash & $7.6 \mathrm{~g} / 100 \mathrm{~g}$ \\
\hline Fat & $1.4 \mathrm{~g} / 100 \mathrm{~g}$ \\
\hline Protein & $8.1 \mathrm{~g} / 100 \mathrm{~g}$ \\
\hline Fiber & $30.3 \mathrm{~g} / 100 \mathrm{~g}$ \\
\hline Carbohydrate & $52.6 \mathrm{~g} / 100 \mathrm{~g}$ \\
\hline
\end{tabular}


Table 2: Total Phenol content in eggplant peels powder(EPP) $(\mathrm{g} / \mathbf{1 0 0 g})$.

\begin{tabular}{|c|c|c|}
\hline $\begin{array}{c}\text { Phenolic } \\
\text { compounds }\end{array}$ & Fresh weight & Dry weight \\
\hline Eggplant peel & $1.94(\mathrm{~g} \mathrm{GAE} / 100 \mathrm{~g})$ & $4.15(\mathrm{~g} \mathrm{GAE} / 100 \mathrm{~g})$ \\
\hline
\end{tabular}

$$
\mathrm{GAE}=\text { Gallic acid equlibrium }
$$

Table 3: Identification of eggplant peels powder (EPP) Phenolic

\begin{tabular}{|c|c|}
\hline $\begin{array}{c}\text { Phenolic compounds } \\
\text { (mg/100g) }\end{array}$ & $\begin{array}{c}\text { Concentration } \\
\mathrm{mg} / \mathbf{1 0 0 g}\end{array}$ \\
\hline Pyrogallic acid & 7.22519 \\
\hline Gallic acid & --- \\
\hline Protocatechuic acid & $\mathbf{2 . 0 6 3 6 7}$ \\
\hline Catechin & --- \\
\hline $\begin{array}{c}\text { Para hydroxy benzoic } \\
\text { acid }\end{array}$ & --- \\
\hline Para coumaric acid & --- \\
\hline Phenol & --- \\
\hline Ortho coumaric acid & 16.74258 \\
\hline Salicylic acid & ---- \\
\hline Coumarin & ---- \\
\hline Quercetin & ---- \\
\hline Cinnamic acid & ---- \\
\hline
\end{tabular}

Table 4: Effect of eggplant peels powder (EPP) on on liver functions of obese rats

\begin{tabular}{|c|c|c|c|c|c|}
\hline $\begin{array}{c}\text { Groups / } \\
\text { Parameters }\end{array}$ & $\begin{array}{c}\text { G1 (- } \\
\text { ve) } \\
\text { Control }\end{array}$ & $\begin{array}{c}\text { G2 (0\%) } \\
\text { EPP }\end{array}$ & $\begin{array}{c}\text { G3 }(1 \%) \\
\text { EPP }\end{array}$ & $\begin{array}{c}\text { G4(2\%) } \\
\text { EPP }\end{array}$ & $\begin{array}{c}\text { G5(4\%) } \\
\text { EPP }\end{array}$ \\
\hline $\operatorname{ALT}(\mathbf{U} / \mathbf{L})$ & $\begin{array}{c}90.60 \pm \\
1.20 d\end{array}$ & $192.30 \pm 0.20 \mathrm{a}$ & $138.5 \pm .15 b$ & $\begin{array}{c}120.4 \pm \\
1.30 \mathrm{c}\end{array}$ & $118.6 \pm .10 \mathrm{c}$ \\
\hline $\operatorname{AST}(\mathbf{U} / \mathbf{L})$ & $\begin{array}{c}11.00 \pm \\
1.10 \mathrm{e}\end{array}$ & $57.62 \pm 1.14 a$ & $\begin{array}{l}41.20 \pm \\
1.05 b \\
\end{array}$ & $\begin{array}{l}32.8 \pm \\
0.20 \mathrm{c}\end{array}$ & $\begin{array}{c}24.90 \pm \\
1.13 d\end{array}$ \\
\hline $\operatorname{ALP}(\mathbf{U} / \mathbf{L})$ & $\begin{array}{c}8.60 \\
\pm .40 \mathrm{e}\end{array}$ & $22.80 \pm 0.10 a$ & $17.30 \pm .20 b$ & $\begin{array}{l}15.9 \pm \\
1.00 c\end{array}$ & $11.55 \pm .30 d$ \\
\hline
\end{tabular}

Each value represents mean $\pm \mathrm{SD}$. value the same column with different superscript letters significantly different $(\mathrm{p} \leq 0.05)$. 
Table (5): Effect of eggplant peels powder (EPP) on serum triglycerides, and serum total cholesterol levels of obese rats.

\begin{tabular}{|c|c|c|c|c|c|}
\hline $\begin{array}{c}\text { Groups / } \\
\text { Parameters }\end{array}$ & $\begin{array}{l}\text { G1 (- ve) } \\
\text { Control }\end{array}$ & $\begin{array}{c}\text { G2 }(0 \%) \\
\text { EPP }\end{array}$ & $\begin{array}{c}\text { G3 }(1 \%) \\
\text { EPP }\end{array}$ & $\begin{array}{c}\text { G4(2\%) } \\
\text { EPP }\end{array}$ & $\begin{array}{l}\text { G5(4\%) } \\
\text { EPP }\end{array}$ \\
\hline $\begin{array}{c}\text { TG } \\
\mathrm{mg} / \mathrm{dl}\end{array}$ & $\begin{array}{l}54.91 \pm \\
0.10 \mathrm{e}\end{array}$ & $\begin{array}{c}134.25 \\
\pm 1.21 \mathrm{a}\end{array}$ & $\begin{array}{c}89.24 \pm 1.10 \\
\text { b }\end{array}$ & $\begin{array}{l}74.73 \pm \\
1.23 \mathrm{c}\end{array}$ & $\begin{array}{c}62.55 \pm \\
0.30 \mathrm{~d}\end{array}$ \\
\hline $\begin{array}{l}\text { T.COL } \\
\mathrm{mg} / \mathrm{dl}\end{array}$ & $\begin{array}{c}95.00 \pm \\
0.10 \mathrm{~h}\end{array}$ & $\begin{array}{c}130.00 \pm \\
1.10 \mathrm{a}\end{array}$ & $\begin{array}{c}122.00 \pm 0.40 \\
b\end{array}$ & $\begin{array}{c}113.00 \\
\pm 0.10 \mathrm{~d}\end{array}$ & $\begin{array}{l}110.00 \\
\pm 0.10 \mathrm{e}\end{array}$ \\
\hline
\end{tabular}

Each value represents mean \pm SD. value the same column with different superscript letters significantly different $(\mathrm{p} \leq 0.05)$.

Table (6): Effect of eggplant peels powder (EPP) on HDL-c, LDL-c and VLDL-c levels of obese rats.

\begin{tabular}{|c|c|c|c|c|c|}
\hline $\begin{array}{c}\text { Groups / } \\
\text { Parameters }\end{array}$ & $\begin{array}{c}\text { G1 (- ve) } \\
\text { Control }\end{array}$ & $\begin{array}{c}\text { G2 (0\%) } \\
\text { EPP }\end{array}$ & $\begin{array}{c}\text { G3 (1\%) } \\
\text { EPP }\end{array}$ & $\begin{array}{c}\text { G4(2\%) } \\
\text { EPP }\end{array}$ & $\begin{array}{c}\text { G5(4\%) } \\
\text { EPP }\end{array}$ \\
\hline $\begin{array}{c}\text { HDL-C } \\
\text { mg/dl }\end{array}$ & $\begin{array}{c}45.50 \pm \\
2.10 \mathrm{a}\end{array}$ & $\begin{array}{c}29.35 \pm 1.41 \\
\mathrm{e}\end{array}$ & $\begin{array}{c}32.65 \pm 0.30 \\
\mathrm{~d}\end{array}$ & $\begin{array}{c}35.50 \pm 1.50 \\
\mathrm{~d}\end{array}$ & $\begin{array}{c}37.80 \\
\pm 1.13 \mathrm{c}\end{array}$ \\
\hline $\begin{array}{c}\text { LDL-c } \\
\mathrm{mg} / \mathrm{dl}\end{array}$ & $\begin{array}{c}38.52 \pm \\
0.10 \mathrm{~d}\end{array}$ & $\begin{array}{c}78.05 \pm 1.20 \\
\mathrm{a}\end{array}$ & $\begin{array}{c}71.50 \pm \\
1.40 \mathrm{~b}\end{array}$ & $\begin{array}{c}62.55 \pm \\
0.10 \mathrm{c}\end{array}$ & $\begin{array}{c}59.69 \pm \\
\mathbf{0 . 2 0} \mathrm{c}\end{array}$ \\
\hline $\begin{array}{c}\text { VLDL-c } \\
\mathrm{mg} / \mathrm{dl}\end{array}$ & $\begin{array}{c}10.98 \pm \\
0.32 \mathrm{c}\end{array}$ & $\begin{array}{c}26.85 \pm 1.13 \\
\mathrm{a}\end{array}$ & $\begin{array}{c}17.85 \pm \\
1.11 \mathrm{~b}\end{array}$ & $\begin{array}{c}14.95 \pm \\
\mathbf{0 . 2 0} \mathrm{c}\end{array}$ & $\begin{array}{c}12.51 \pm \\
\mathbf{0 . 2 0} \mathrm{c}\end{array}$ \\
\hline
\end{tabular}

HDL-c $=$ High density lipoprotein

LDL-c $=$ Low density lipoprotein

VLDL-c $=$ Very low density lipoprotein.

Each value represents mean \pm SD. value the same column with different superscript letters significantly different $(p \leq 0.05)$. 
Table (7): Effect of eggplant peels powder (EPP) on atherogenic indices levels of obese rats.

\begin{tabular}{|c|c|c|c|c|c|}
\hline $\begin{array}{l}\text { Groups / } \\
\text { Parameters }\end{array}$ & $\begin{array}{l}\text { G1 (- ve) } \\
\text { Control }\end{array}$ & $\begin{array}{ll}\text { G2 } & (0 \%) \\
\text { EPP } & \end{array}$ & $\begin{array}{l}\text { G3 }(1 \%) \\
\text { EPP }\end{array}$ & $\begin{array}{l}\text { G4(2\%) } \\
\text { EPP }\end{array}$ & $\begin{array}{l}\text { G5(4\%) } \\
\text { EPP }\end{array}$ \\
\hline AI (mg/dl) & $\begin{array}{l}1.48 \pm 0.10 \\
\text { d }\end{array}$ & $4.46 \pm 0.30 \mathrm{a}$ & $\begin{array}{l}3.55 \pm 0.10 \\
\text { b }\end{array}$ & $\begin{array}{l}2.30 \pm 0.20 \\
\text { c }\end{array}$ & $\begin{array}{l}2.40 \pm \\
0.20 \mathrm{c}\end{array}$ \\
\hline $\begin{array}{l}\text { CRR } \\
(\mathrm{mg} / \mathrm{dl})\end{array}$ & $\begin{array}{l}2.09 \pm \\
0.13 c\end{array}$ & $4.43 \pm 0.11 \mathrm{a}$ & $\begin{array}{l}3.74 \pm \\
0.12 b\end{array}$ & $\begin{array}{l}3.18 \pm \\
0.15 b\end{array}$ & $\begin{array}{l}2.91 \pm \\
0.10 b\end{array}$ \\
\hline $\begin{array}{l}\text { CRI } \\
(\mathrm{mg} / \mathrm{dl})\end{array}$ & $\begin{array}{l}0.85 \pm \\
0.33 c\end{array}$ & $2.66 \pm 0.10 \mathrm{a}$ & $\begin{array}{l}2.19 \pm \\
0.14 a\end{array}$ & $\begin{array}{l}1.76 \pm \\
0.11 b\end{array}$ & $\begin{array}{l}1.58 \pm \\
0.12 b\end{array}$ \\
\hline $\mathrm{AF}$ (mg/dl) & $\begin{array}{l}49.50 \pm \\
0.23 e\end{array}$ & $100.65 \pm 0.61 \mathrm{a}$ & $\begin{array}{l}89.35 \pm \\
0.50 b\end{array}$ & $\begin{array}{l}77.50 \pm \\
0.26 \mathrm{c}\end{array}$ & $\begin{array}{l}72.20 \pm \\
0.35 d\end{array}$ \\
\hline $\mathrm{AC}(\mathrm{mg} / \mathrm{dl})$ & $1.09 \pm 0.11 \mathrm{~d}$ & $3.43 \pm 0.15 a$ & $2.78 \pm 0.12 a$ & $2.18 \pm 0.14 b$ & $\begin{array}{l}1.91 \pm \\
0.12 \mathrm{c}\end{array}$ \\
\hline
\end{tabular}

$\mathrm{AI}=\mathrm{Atherogenic}$ Index in Plasms

$\mathrm{CRR}=$ Cardiac Risk Ratio

$\mathrm{AF}=$ Atherogenic Fraction

$\mathrm{AC}=$ Atherogenic Coefficient

$\mathrm{CRI}=$ Castellis Risk Index

Each value represents mean $\pm \mathrm{SD}$. value the same column with different superscript letters significantly different $(\mathrm{p} \leq 0.05)$. 


\section{REFERENCES}

- A.O.A.C. (2000): Association of Official Agricultural Chemisti. Official Methods Of Analysis. $17^{\text {th }}$ Ed Vol. 11. A.O.A.C. Washington. USA.

- Aguilar EC; Queiroz MGMN and Oliveira DA (2011): Serum lipid profile and hepatic evaluation in mice fed diet containing pequinut or pulp (Caryocar brasiliense Camb.). Ciênc. Tecnol. Aliment., Campinas, 31(4): 879-883, out.-dez. 2011.

- AIN. American Institute of Nutrition. (1993): Purified diet for laboratory Rodent, Final report., J. Nutrition. 123:1939-1951.,and O.compactum Benth. J. essential oil Res. 8 (6):657-664.

- Azevedo, L., Alves de lima, P.L., Gomes, J.C., Stringheta, P.C., Ribeiro, D.A. and Salvadori, D.M. (2007): Differential response related to genotoxicity between eggplant (Solanum melongena) skin aqueous extract and its main purified anthocyanin (delphinidin) in vivo. Food Chem. Toxico., 45 (5): 852-8.

- Ben-Hammouda, M.; Kremer, R.J.; Minor, H.C. and Sarwar, M. (1995): A chemical basis for differential allelopathic potential of sorghum hybrids on wheat. J Chem. Ecol., 21:775-786.

- Bhardwaj S; Bhattacharjee J; Bhatnagar MK and Tyagi S (2013): Atherogenic index of plasma, castelli risk index and atherogenic coefficient- new parameters in assessing cardiovascular risk. IJPBS. 3(3):359-364.

- Biggerstaff, K.Dad Wooten, J.S. (2004): Understanding lipoproteins as transporters of cholesterol and other lipids". Adv Physiol Educ. 28 (1-4): 105-6.

- Botelho, F.V., Eneas, L.R., Cesar, G.C., Bizzotto, C.S., Tavares, E., Oliveira, F.A., Gloria, M.B.A, Silvetre, M.P.C, Arantes, R.M.E. and Alvarez-leite, J.I. (2004): Effects of eggplant (Solanum melomgena) on the atherogenesis and oxidative stress in LDL receptor knock out mice (LDLR-1-) Food and Chemical Toxicology, 42: 1259-1267.

- Capriles, P.V., Dias, A.P., Costa, T.E., Oliveira, M.B., Faria, M. V., Moura, E.G., Abreu, B.A., and Bernardo-Filho, M. (2002): Effect of eggplant (Solanum melongena) extract on the in vitro labeling of blood elements with technetium - 99m and on the biodistribution of sodium pertechnetate in rats. Cell Mol. Biol. (Noisy-le-grand), 48 (7): 771-6.

- Carmena, R.; Duriez, P. and Fruchart, J.C. (2004): Atherogenic lipoprotein particles in atherosclerosis". Circulation. 109 (23 Suppl 1): III2-7.

- Cherem, A.R., Tramote, V.L.C.G., Fett, R. and van Dokkum, W. (2007): The effect of the eggplant core on blood lipid concentrations in hypercholesterolemic guinea pigs (Cavia porcellus). Revista Brasileira de Plantas Medicines, 9 (1): 51-60.

- Clinica Chimica Acta (1980): 105, 147-172. (Chemical kits).

- Duke, J.A., Bogenschutz-Godwin, M.J., cellier, J. and Duke, P-A K. (2002): Hand Book of Medicinal Herbs. 2 nd Ed., CRC press, New York, P. 267. 
- Ejoh, A.R., Mbiapo, F.T.; and Fokou, E. (1996): Nutrient composition of the leaves and flowers of calo casia esculenta and the fruits of Solanum melongena. Plant Foods for Human Nutrition, 49: 107-112.

- Fossati, P. (1982): Principle. Clin.Chem., 28: 2077 (Chemical Kits).

- Friedman, M., Henika, P.R., and Mackey, B.E. (1996): Feeding of potato. Tomato and eggplant alkaloids affects food consumption and body and liver weights in mice. J Nurt., 126 (4): 989-99.

- Friedwaid, W.T. (1972): Determination of HDL. Clin. Chem., 18: 499. (Chemical Kits).

- Fung M.; Bebb R. and Frohlich J. (2011): Follow-up of type III hyperlipoproteinaemia in a child. Lancet. 22-29;358(9299):2171.

- Guimaraes, P.R., Galvao, A.M.P., Batista, C.M., Azevedo, G.S., oliveira, R.D., lamounier, R.P., viera, E.C. and Alvarez-leite, J.I. (2000): Eggplant (Solanum melongena) infusion has a modest and transitory effect on hypercholesterolemic subjects-Braz J med Biol Res., 33 (9): 1027-1036.

- Hafkenscheid, J.C. (1979): Determination of GOT. Clin. Chem., 25:155.

- Hanson, P.M., Yang, R.-Y., Tsou, S.C.S., Ledesma, D., Engle, L., and Lee, T.-C. (2006): Diversity in eggplant (Solanum melongena) for superoxide scavenging activity, total phenolics, and ascorbic acid. J. Food Composition and Analysis, 19: 554-600.

- Helmja, K., Vaher, M., Gorbatsova, J., and KalJurand, M. (2007): Characterization of bioactive compounds contained in vegetables of the Solanaceafamily by apillary electrophoresis. Proc. Estonian Acad. Sci. Chem., 56 (4): 172-186.

- Helmja, K, Vaher, M., Pussa, T., and KalJurand, M. (2009): Analysis of the stable free radical scavenging capability of artificial polyphenol mixtures and plant extracts by capillary electrophoresis and liquid chromatography- diode array detection-tandem mass spectrometry. Journal of chromatography A., 1216: 2417-2423.

- Hooper, L.; Summerbell, C.D.; Thompson, R.; Sills, D.; Roberts, F.G.; Moore, H.J. and Davey Smith, G.(2012): Reduced or modified dietary fat for preventing cardiovascular disease". Cochrane Database Syst Rev. May 16;(5):CD002137.

- Huang, H., Chang, C.; Tso, T.K.; Huang, J.; Change, W.; and Tsia, y. (2004): Antioxidant activities of various fruits and vegetables producted in Taiwan. International Journal of Food Sciences and Nutrition, 55 (5): 423-429.

- Huang, Z., Wang, B., Eaves, D.H., Shikany, J.M., and Pace, R.D. (2007): Total phenolics and antioxidant capacity of indigenous vegetables in the southeast United States: Alabama collaboration for cardiovascular Equality project. J Food Sci Nutr., 18: 1-9.

- Ito, M.K.; McGowan, M.P. and Moriarty, P.M.(2011): Management of familial hypercholesterolemias in adult patients: recommendations from the National Lipid Association Expert Panel on Familial Hypercholesterolemia". J Clin Lipidol. Jun;5(3):S38-45.

- Jenkins, D.J., Kendall, C.w., Marchie, A., Faulkner, D.A., Wong, J.M., de Souza, R., Emam, A., Parker, T.L., Vidgen, E., Trautwein, E.A., Lapsley, K.G., Josse, R.G., Leiter, L.A., Singer, W. and 
Connelly, P.W. (2005): Direct comparison of a dietry portfolio of cholesterol lowering foods with a statin in hypercholesterolemic participants. Am J Clin Nutr., 81 (2): 339-40.

- Kahlon a , T.S.; Champan, M.H.; and Smith , G.E. (2007): In vitro binding of bile acids by okra, beets, asparagus, eggplant, turnips, green beans, carrots, and cauliflower. Food Chemistry, 103: 676-680.

- Kahlon B , T.S., Chiu, M.-C. M. and Chapman, M.H. (2007): Steam cooking significantly improves in vitro bile acid binding of beets, eggplant, asparagus, carrots, green beans, and cauliflower. Nutrition Research, 27: 750-755.

- Kala, A., and Prakash, J. (2006): The comparative evaluation of the nutrient composition and sensory attributs of four vegetables cooked by different methods. International Journal of Food Science and Technology, 41: 163-171.

- Kayamori, F., and Igarashi, K. (1994): Effects of dietary nasunin on the serum cholesterol level in rats. Biosci Biotech. Biochem., 58: 570571.

- Kontush, A. and Chapman, M. J.(2006): Functionally defective highdensity lipoprotein: a new therapeutic target at the crossroads of dyslipidemia, inflammation, and atherosclerosis".Pharmacol Rev. Sep;58(3):342-74.

- Kritchevsky, D., Tepper, S.A. and Story, J.A. (1975): Influence of an eggplant (Solanum melongena) preparation on cholesterol metabolism in rats. Experimental Pathology, 10: 180-183.

- Kwon, y.I., Apostolidis, E. and Shetty, K. (2008): In vitro studies of eggplant (Solanum melongena) phenolics as inhibitors of key enzymes relevant for type $\mathrm{z}$ diabetes and hypert ension. Bioresource Technology, 99: 2981-2988.

- Lans, C.A. (2006): Ethnomedicines used in Trinidad and Tobago for urinary problems and diabetes mellitus. J Ethnobiol Ethnomed., Oct 13;2:45.

- Lee, R. and Nieman, D. (1996): Nutrition Assessment. 2nd Ed., Mosby, Missouri, USA.

- Meda , A., Lamien , C,E., Romito , M., Millogo, J. and Nacoulma , O. G. (2005): Determination of the total phenolic , flavonoid and praline contents in burkina fasan honey, as well as their radical scavenging activity. Food Chemistry, 91: $571-577$.

- Moss, D.W. (1982): Alkaline phosphatase isoenzymes. Clin. Chem., 28: 2007-2016.

- Nisha, P., Nazar, p.A., and Jayamurthy, P. (2009): Acomparative study on antioxidant activities of different varieties of Solanum melongena. Food and Chemical Toxicology, 47: 2640-2644.

- Noda, y., Kneyuki, T., Igarashi, K., Mori, A., and packer, L. (2000): Antioxidant activity of nasunin, an anthocyanin in eggplant peels. Toxicology, 148: 119-123.

- Oboh, G., Ekperigin, M.M.; and Kazeem, M.I. (2005): Nutritional and haemolytic properties of eggplants (Solanum macrocarpon) leaves. Journal of Food Composition and Analysis, 18: 153-160. 
- Raigon, M.D., Prohens, J., Munoz-falcon, J.E., and Nuez, F. (2008): Comparison of eggplant landraces and commercial varieties for fruit content of phenolics, minerals, dry matter and protein. J. Food Composition and Analysis, 21: 370-376.

- Sameer A.;Juraj K. and Peter D Reaven (2011): Postprandial hyperlipidemia, endothelial dysfunction and cardiovascular risk: focus on incretins". Cardiovascular Diabetology. 38(3): 1475-2840.

- SAS (1988): SAS Users Guide: Statistics version 5th Ed., SAS. Institute Inc., Cary N.C.

- Schermer, S. (1967): The Blood Morphology of Laboratory Animal. Longmans, Printed in Great Britain, Green and Co.LTd, P.350.

- Silva, G.E., Takahashi, M.H., Eik Filho, W., Albino, C.C., Tasim, G.E., Serri Lde, A., Assef, A.H., cortez, D.A. and Bazotte, R.B. (2004): Absence of hypolipidemic effect of Solanum melongena, L.(eggplant) on hyperlipidemic patients. Arq Bras Endocrinol Metabol., 48 (3): 368-73.

- Sudheesh, S., Presannakumar, G., Vijayakumar, J. and Vijayalakshmi, R.N. (1997): Hypolipidemic effect of flavonoids from Solanum melongena. Plant Foods for Human Nutrition, 51: 321-330.

- Temple, N.J., Wilson, T., Jacobs, D.R., and Ludwig, D.S. (2006): Nutritional Health, Strategies for Disease Prevention. 2 Ed Edition. Humana press. Totowa, New Jersey. P. 51- 52, 173.

- Thomas, L. (1992): Labor and Diagnose, 4 th Ed., (Chemical Kits).

- Usoro CAO; Adikwuru CC; Usoro IN and Nsonwu AC(2006): "Lipid Profile of Postmenopausal Women in Calabar, Nigeria". Pak. J. Nutr. 5:79-82.

- Varghese, M.J.(2014): Familial hypercholesterolemia: A review". Ann Pediatr Cardiol .May; 7(2):107-17.

- Yeh, C-T., and Yen, G.-C. (2005): Effect of vegetables on human phenolsulfotransferases in relation to their antioxidant activity and total phenolics. Free Radical Reserch, 39 (8): 893-904.

- Young, D.S. (1975): Determination of GOT. Clin. Chem., 22 (5): 1 - 21.

- Zaro, M. J.; Ortiz, L. C.; Keunchkarian, S. and Chaves, A. R. (2015): Chlorogenic acid retention in white and purple eggplant after processing and cooking. LWT - Food Science and Technology, 64, $802-808$.

- Zevnik, N. (2009): Exceptional eggplant. www.BetterNutrition.com P.25. 
التأثير الخافض لاهون الام لمسحوق قشور الباذنجان علي الفئران

\title{
المصابة بالسمنة
}

\author{
د/ أمل ناصف زكي
}

مدرس بقسم التغذية وعلوم الأطعمة. كلية الأقتصاد

المنزلى · جامعة المنوفية

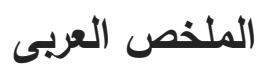

الباذنجان يعتبر واحدا من الخضروات الغنية بمضادات الأكسدة. كما يحتوي علي

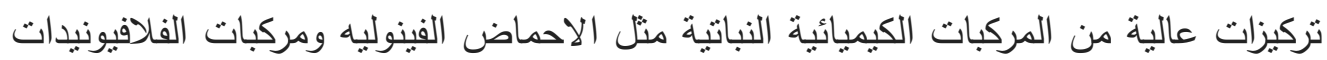
والمعروفة بنشاطها العالي كمضاد لاكسده. وفي هذا البحث، قمنا بدراسة تأثنر مسحوق قنشور الباذنجان المجفف في خفض مستوي الكوليستيرول ودهون الدم لدي الفئران المصابة بالسمنة

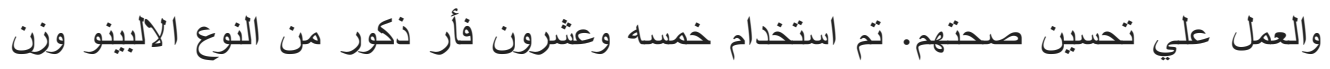

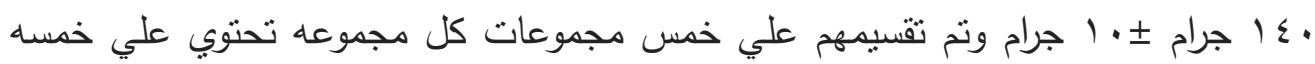
فئران وتمت تغذيتهم علي غذاء عالي الدهون (•r\% دهون حيوانيه) وذلك لإصابتهم بالسمنه ورفع مستوي كل من الكوليستيرول ودهون الدم لديهم. المجموعه الاولي (الكنترول) هي

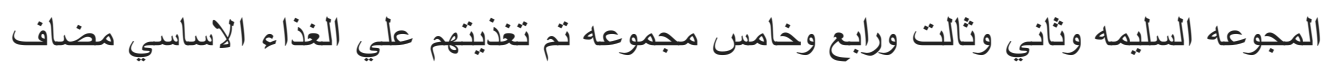

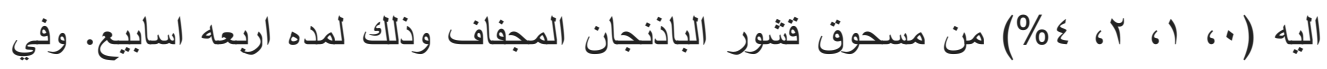

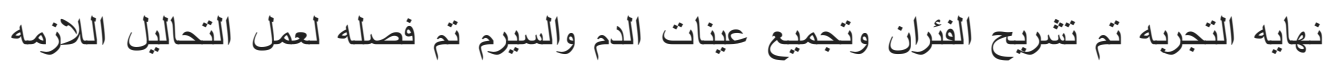

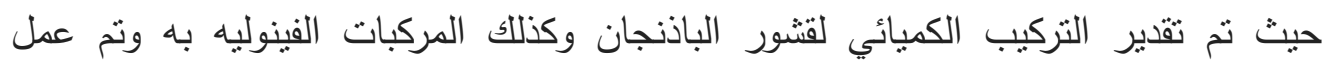
تحاليل بيوكيميائيه لقياس مستويات الكوليستيرول الكلي والجليسريدات الثناثيه ومؤشرات دهون الدم وكذلك مؤشرات تصلب الشرايين وتم تقدير انزيمات وظائف الكبد، وكثفت البيانات الخاصه بالفئران المصابه بالسمنه العديد من التغيرات المعنويه في المؤشرات البيوكيمائيه، وكانت الخلاصه ان الفئران المصابه بالسمنه والتي تم تغذيتها علي الغذاء الاساسي مضاف باف له له مسحوق قشور الباذنجان المجفف بنسبه ؛ \% ادت الي تحسن في مستويات دهون الدم حيث كان له تأثير الخافض لدهون الدم المرتفعه مقارنه بغيره من التركيزات المستخدمه. الكلمات الدلاليه: الفئران - مسحوق قشور الباذنجان - ارتفاع دهون الدم - دهون الدم. 